FACTA UNIVERSITATIS

Series: Mechanical Engineering Vol. 18, Nº 3, 2020, pp. 513 - 524

https://doi.org/10.22190/FUME171212010P

Original scientific paper

\title{
A STUDY OF THE ENVIRONMENTAL KUZNETS CURVE FOR TRANSPORT GREENHOUSE GAS EMISSIONS IN THE EUROPEAN UNION
}

\author{
Nikola Petrović ${ }^{1}$, Nebojša Bojović ${ }^{2}$ Marijana Petrović ${ }^{2}$ \\ Vesna Jovanović ${ }^{1}$ \\ ${ }^{1}$ Faculty of Mechanical Engineering, University of Niš, Serbia \\ ${ }^{2}$ Faculty of Transport and Traffic Engineering, University of Belgrade, Serbia
}

\begin{abstract}
In view of the European Union as one of the main polluters in the word and the fact that GDP per capita in the European Union is equivalent to the 282 percent of the world's average, it is interesting to study the relationship between transport GHG emissions and the economic activity within the European Union. In the paper, the authors check the environment Kuznets curve hypothesis for members of the EU over the period 2000-2014. The analysis results show that an inverse-U relationship exists between transport GHG emissions and GDP per capita. At the same time, the results indicate that the change of economic structure has influenced the transport GHG emissions in the developed countries, that is, in the countries that record a higher level of GDP per capita.
\end{abstract}

Key Words: Transport, GHG Emissions, Environmental Kuznets Curve, GDP per Capita, European Union

\section{INTRODUCTION}

The development of the world economy as well as the economic development of the transition countries is accomplished in a very turbulent environment [1]. Transport represents an important economic activity in the developed countries as well as in the transition ones. The development of an effective and efficient transport system contributes to the products becoming more competitive in the domestic and global market. Firstly, the industrial development and, later, the international trade intensification have contributed to the accelerated development of transport. However, this has, in turn, resulted in transport

Received December 12, 2017 / Accepted April 10, 2018

Corresponding author: Nikola Petrović

Faculty of Mechanical Engineering, University of Niš, A. Medvedeva 14, 18000 Niš, Serbia

E-mail: petrovic.nikola@masfak.ni.ac.rs 
now becoming an economic activity with the fastest growing impact on environmental degradation [2]. On the one hand, transport plays important roles in socio-economic activities and improvement of people's well-being, while, on the other, transport represents one of the major emitters of hazardous substances that affect the quality of air and the formation of tropospheric ozone. Greenhouse Gas (GHG) emissions account for $70 \%$ of the total GHG emissions from humans with the major emission sources from fossil fuels of energy supply and transport [3].

The rapid development of transport together with the related environmental problems pertaining to air pollution and GHG emissions have been a caution to the world [4]. Following the power generation sector, the global transport sector is the second largest sector generating GHG emission causing $23 \%$ of total GHG emissions worldwide [5]. "Around $75 \%$ of the global greenhouse gas emissions is caused by $\mathrm{CO}_{2}$ " [6]. Transport is responsible for nearly one quarter of global energy related carbon dioxide emissions while $75 \%$ of these emissions are due to road transport energy use [7].

Since 1991, when economists first reported on a systematic relationship between income changes and environmental quality, the relationship known as the Environmental Kuznets Curve (EKC) has become standard fare in technical conversations about environmental policy [8]. The EKC statistical relationship suggests that as development and industrialization progress, environmental quality decreases due to an increasing emission of pollutants. Much later, in the post-industrial stage, cleaner technologies and a shift to information and service-based activities combine with a growing ability and willingness to enhance environmental quality [9]. The literature related to the examination of the EKC validity includes various dependent and independent variables. What is observed as dependent variables are indicators of environmental degradation, i.e. the indicators of environmental quality (such as $\mathrm{CO}_{2}, \mathrm{SO}_{2}$, sulfur, arsenic, lead emissions; deforestation; water pollution; and dark matter), while the following indicators are observed as independent variables together with per capita income: income inequality, trade openness, institutional quality, strictness of environmental regulations, and corruption [10].

Bearing in mind that the industrial development in its early stages contributed to an increased environmental degradation as well as that the literature has not paid much attention so far to the analysis of the quantification of the industrial development effect, along with the service sector development influence on transport GHG emissions, the paper draws particular attention to the influence of the industrial share in the gross domestic product (GDP) and the effects of the service sector in GDP on GHG emissions. The environment in the transition countries is cleaned up quickly because of rising energy prices and penalizing of energy-intensive activities [11, 12]. Therefore, special emphasis will be placed on the interdependence between GDP per capita and transport GHG emissions in the developed and transition countries that are members of the EU.

Starting from the abovementioned, the purpose of this paper is to quantify the influence of the economic development on transport GHG emissions in the example of certain EU members. The economic growth includes only quantitative changes while the economic development represents a broader category including both quantitative and qualitative changes [13]. The aims of the paper are: 1) analysis of the interdependence between transport GHG emissions and GDP per capita; 2) analysis of the effects of changes in the economic structure, i.e. changes in the service sector participation in GDP ontransport GHG emissions. The following hypotheses will be tested in the paper: 
$\mathrm{H}_{1}$ - an inverted-U-shaped relationship exists between GDP per capita and transport GHG emissions; and,

$\mathrm{H}_{2}$ - changes in the economic structure have a significant influence on transport GHG emissions.

\section{REVIEW OF RELATED LITERATURE}

Three main approaches have dominated the literature on the drivers of pollution emissions and other environmental impacts [14, 15] - the IPAT identity, convergence approaches and the environmental Kuznets curve. IPAT (abbreviated from Impact, Population, Affluence and Technology) expresses the idea that environmental impact results from the following factors: population, affluence and technology. This identity was proposed by Ehrlich and Holdren as a way of quantifying human impact on environment [16]. The convergence approaches hypothesize that emissions grow more slowly in emissions intensive countries than in less emissions intensive ones [17].

According to Kuznets, per capita income increases and so does income inequality at first, but income inequality starts declining as economic growth continues [18]. This interdependence between per capita income and income inequality is known as the Kuznets Curve. Therefore, the question of whether economic growth causes environmental degradation has become a central issue of discussion since publication of the Bruntland report in 1987 [19].

In the 1990s, the Kuznets curve took on a new form of existence. Instead of an inverted-U-shaped relationship between economic growth and economic inequality that represented the original Kuznets curve, what was examined was an inverted-U-shaped relationship between economic growth and environmental degradation that is known as the EKC. The first results of the empirical EKC studies appeared independently in the following working papers: an NBER working paper as part of a study of the environmental impacts of NAFTA [20], the World Bank's 1992 World Development Report [21] and a Development Discussion paper as part of a study for the International Labour Organization [22]. Grossman and Krueger first pointed out an inverted-U-shaped relationship between $\mathrm{SO}_{2}$ and smoke [20], on the one hand, and per capita income, on the other, while Panayoton first named this relationship as the EKC [22].

The EKC hypothesis is tested empirically in the cases of many countries and regions. However, the results of the various research studies are different and depend on the observed countries, regions and selected environmental quality indicators. Numerous studies have examined the relationship between environmental degradation and per capita income. Their findings confirmed the presence of an inverse-U-shaped relationship between environmental quality and per capita income [23-31]. Those studies have shown that environmental degradation increases at low levels of per capita income while it later decreases at high levels of per capita income.

Recently, special attention has been paid to the effect of transport on environmental and air quality in the literature. Alshehry and Belloumi check for the environmental Kuznets curve hypothesis for Saudi Arabia over the period 1971-2011 [19]. They find that the inverse-U relationship does not exist between transport $\mathrm{CO}_{2}$ emissions and economic growth in Saudi Arabia. The paper will attempt to test the EKC in the example of certain EU members, i.e. examine whether an inverse-U relationship between GHG emissions and GDP per capita exists in the EU. 


\section{RESEARCH METHODOLOGY}

For the purpose of achieving the defined research objective several methods are applied. Namely, this research relies on the following methods:

- Cluster analysis,

- Correlation analysis, and,

- Regression analysis.

The cluster analysis comprises a range of methods for classifying multivariate data into a number of clusters based on the observed values of several variables for each individual. By organizing multivariate data into such clusters or segments, clustering can help reveal the characteristics of any structure. This analysis has proven useful in a wide range of areas such as psychology, market research and bioinformatics. It was used to examine the heterogeneity of the observed countries in terms of transport GHG emissions and GDP per capita in the period 2000-2014.

The correlation analysis is a method of statistical evaluation used to study the strength of a relationship between continuous variables. The paper employs the Pearson correlation coefficients which can only be given the values from -1 to +1 . The sign shows whether the correlation in question is positive or negative. The absolute value of that coefficient shows the strength of connection. A perfect correlation, which is either -1 or +1 , shows that the value of one variable can be determined with certainty if one knows the value of the other variable. On the other hand, the correlation that is equal to zero shows that there is no connection between the observed variables. By means of the correlation analysis the interdependence between GDP per capita and transport GHG emissions is explored.

The regression analysis represents a technique that can be used to examine the connection between a continuous dependent variable and many independent variables. It is based on correlation; yet it enables a more sophisticated study of interrelations within a set of variables. It provides an assessment of the model as a whole and the relative contribution of all the variables comprising it. The regression analysis was used to determine the effect that the levels of GDP per capita, the industry share in GDP and that of service in GDP exert on transport GHG emissions.

Information base of research presents the Statistical Pocketbook [32], as well as the data of the World Bank [33].

\section{RESEARCH RESULTS AND DISCUSSION}

The empirical part of the paper is organized into the following segments:

- Testing heterogeneity of the EU countries in terms of GDP per capita and transport GHG emissions;

- Analysis of GDP per capita and transport GHG emissions interdependence; and,

- Analysis of influence of GDP per capita, the share of service as well as that of industry in GDP on transport GHG emissions. 


\subsection{Examining the heterogeneity of the EU countries in terms of GDP per capita and transport GHG emissions}

Using the cluster analysis the EU member states were grouped according to GDP per capita and transport GHG emissions during the $21^{\text {st }}$ century. The results of descriptive statistics for each cluster are given in Table 1 (prepared by the authors - STATISTICA 8.0).

Table 1 Members of Cluster Number and Distances from Respective Cluster Center

\begin{tabular}{lrlrlr}
\hline \multicolumn{2}{c}{ Cluster 1 } & \multicolumn{2}{c}{ Cluster 2 } & \multicolumn{2}{c}{ Cluster 3 } \\
\hline Members & Distance & Members & Distance & Members & Distance \\
Cyprus & 1902.826 & Austria & 4150.63 & Bulgaria & 4013.021 \\
Greece & 1511.792 & Belgium & 5588.99 & Croatia & 757.332 \\
Italy & 6152.557 & Denmark & 3132.07 & Czech Republic & 3665.652 \\
Malta & 4128.699 & Finland & 3777.62 & Estonia & 1847.923 \\
Portugal & 3094.260 & France & 7549.23 & Hungary & 912.204 \\
Slovenia & 2646.965 & Germany & 6615.41 & Latvia & 659.485 \\
Spain & 2338.866 & Ireland & 2884.98 & Lithuania & 623.774 \\
& & Luxemburg & 31304.73 Poland & 663.010 \\
& & Netherland & 2004.20 & Romania & 3083.448 \\
& & Sweden & 1769.98 & Slovak Republic & 2124.844 \\
& & United Kingdom & 6421.15 & & \\
\hline
\end{tabular}

In the first cluster are the members of the European Union which recorded lower average values of GDP per capita and transport GHG emissions compared to the second cluster, namely: Cyprus, Greece, Italy, Malta, Portugal, Slovenia and Spain. Up to 2008 the observed countries recorded an increase in GDP per capita, i.e. an increase in transport GHG emissions up to 2007, followed by a decrease in both GDP per capita and transport GHG emissions in the ensuing period. It can be concluded that when the observed countries reached the level of GDP per capita (2008) that could contribute to a decrease in transport GHG emissions, they began to record a decrease in GDP per capita due to the financial crisis. At the same time, it can be shown that the observed countries, contrary to the countries that belong to the second and third cluster, experienced a decrease in GDP per capita from 2008 to 2014. That is, the countries of the second and third cluster suffered a decrease in GDP per capita in 2009 and 2010 as a consequence of the financial crisis, but recorded an increase in GDP per capita after that.

In the second cluster there are the countries that recorded the highest average values of GDP per capita and the highest average values of transport GHG emissions, which are: Austria, Belgium, Denmark, Finland, France, Germany, Ireland, Luxemburg, Netherlands, Sweden and United Kingdom. It can be concluded that this cluster comprises the highly developed EU countries as well as the biggest polluters of air and environment. However, it has to be pointed out that the observed countries have reached the level of GDP per capita where any next increase in GDP per capita would contribute to a decrease in transport GHG emissions.

In the third cluster are the countries that recorded the lowest average values of GDP per capita and transport GHG emissions, which are: Bulgaria, Croatia, Czech Republic, Estonia, Hungary, Latvia, Lithuania, Poland, Romania and Slovak Republic. This cluster includes all the transition countries that are members of the EU, except Slovenia that belongs to the first cluster. 

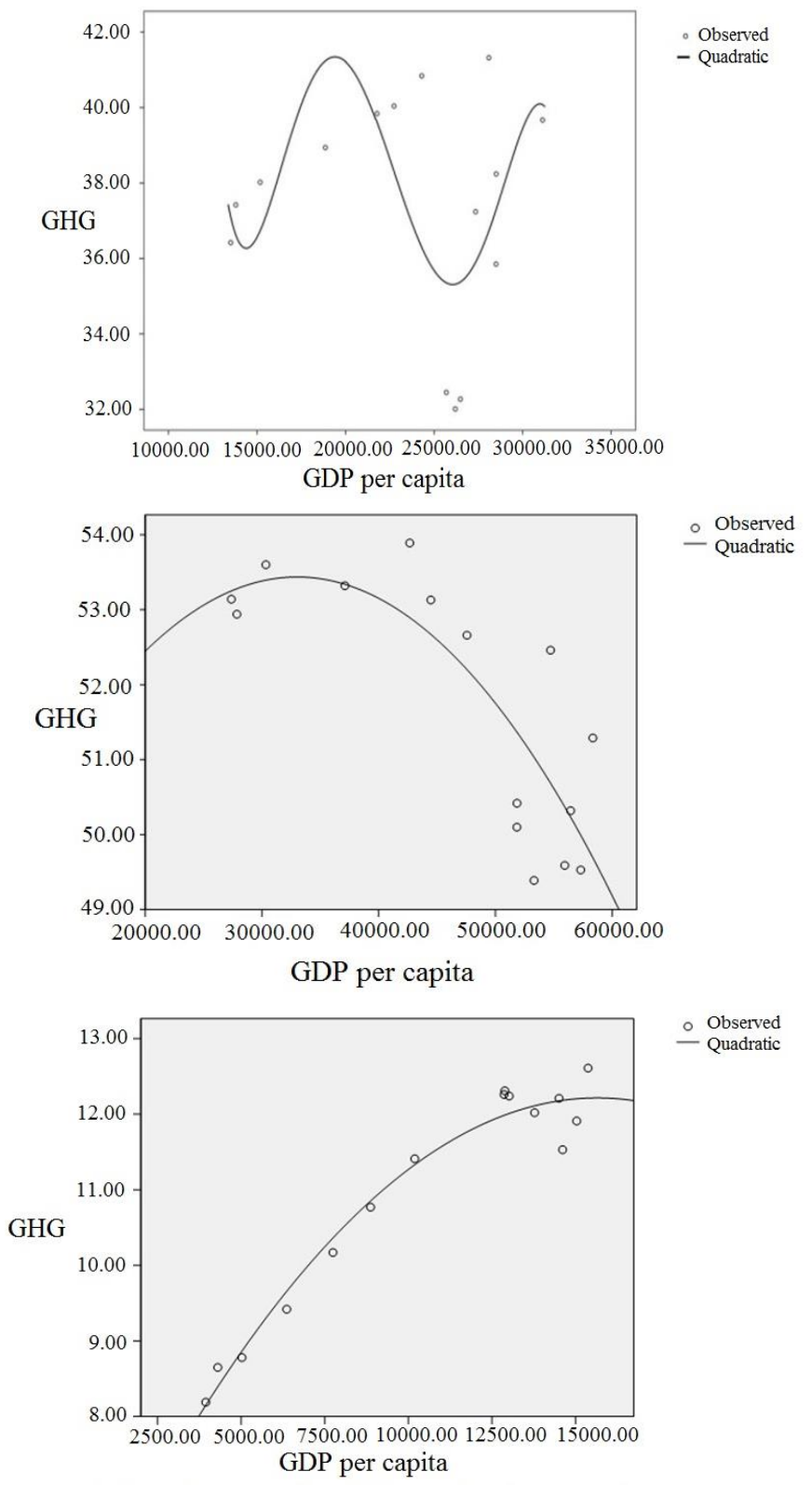

Fig. 1 Changes in average values of GDP per capita and transport GHG emissions in the 1st, 2nd and 3rd cluster, respectively, in the period from 2000 to 2014

Based on the foregoing it can be concluded that the developed countries recorded a high level of GDP per capita and a high level of transport GHG emissions while the transition countries recorded a low level of GDP per capita and a low level of transport 
GHG emissions. At the same time, it can be shown that any increase in GDP per capita in the transition countries (Slovenia excluded) leads to an increase in transport GHG emissions, i.e. the transition countries have not yet reached the level of GDP per capita whose increase would contribute to a decrease in transport GHG emissions (Fig. 1).

\subsection{Analysis of GDP per capita and transport GHG emissions interdependence}

Tables 2, 3 and 4 (prepared by the authors - SPSS Statistics 19.0) contain the results of the correlation analyses. For the first cluster, the results indicate that there is a negative correlation between GDP per capita and transport GHG emissions. Correlation is not statistically significant because the value of Sig. is not less than 0.05.

Table 2 Correlation analysis between GDP per capita and GHG for cluster 1

\begin{tabular}{llcc}
\hline & & GDP per capita & Transport GHG \\
\hline \multirow{3}{*}{ GDP per capita } & Pearson Correlation & 1 & -0.064 \\
& Sig. (2-tailed) & & 0.820 \\
& $\mathrm{~N}$ & 15 & 15 \\
\hline \multirow{3}{*}{ Transport GHG } & Pearson Correlation & -0.064 & 1 \\
& Sig. (2-tailed) & 0.820 & \\
& $\mathrm{~N}$ & 15 & 15 \\
\hline
\end{tabular}

The results for the second cluster indicate that there is a negative correlation between GDP per capita and transport GHG emissions, i.e. an increase of GDP per capita is followed by a decrease in transport GHG emissions of the developed EU member states. Correlation is statistically significant because the value of Sig. is less than 0.05 .

Table 3 Correlation analysis between GDP per capita and GHG for cluster 2

\begin{tabular}{llcr}
\hline & & GDP per capita & Transport GHG \\
\hline \multirow{3}{*}{ GDP per capita } & Pearson Correlation & 1 & $-0.753^{* * *}$ \\
& Sig. (2-tailed) & & 0.001 \\
& $\mathrm{~N}$ & 15 & 15 \\
\hline \multirow{3}{*}{ Transport GHG } & Pearson Correlation & $-0.753^{* *}$ & 1 \\
& Sig. (2-tailed) & 0.001 & 15 \\
& $\mathrm{~N}$ & 15 & \\
\hline & . Correlation is significant at the 0.01 level (2-tailed)
\end{tabular}

The results for the third cluster indicate that there is a positive correlation between GDP per capita and transport GHG emissions, i.e. an increase of GDP per capita is followed by an increase in transport GHG emissions of the transition countries. Correlation is statistically significant because the value of Sig. is less than 0.05 .

Based on the above, it can be concluded that an inverted-U-shaped relationship exists between transport GHG emissions and GDP per capita in the developed and transition countries. However, it is necessary to point to the countries that belong to the first cluster and that still record a decrease in GDP per capita in the longer run after the global financial crisis. It can be concluded that the inverted-U-shaped relationship exists between GDP per capita and transport GHG emissions for the highly developed and transition countries in the European Union, i.e. that hypothesis $\mathrm{H}_{1}$ has been confirmed. 
Table 4 Correlation analysis between GDP per capita and GHG for cluster 3

\begin{tabular}{llcc}
\hline & & GDP per capita & Transport GHG \\
\hline \multirow{3}{*}{ GDP per capita } & Pearson Correlation & 1 & $0.959^{* * *}$ \\
& Sig. (2-tailed) & & 0.000 \\
& $\mathrm{~N}$ & 15 & 15 \\
\hline \multirow{2}{*}{ Transport GHG } & Pearson Correlation & $0.959^{* * *}$ & 1 \\
& Sig. (2-tailed) & 0.000 & 15 \\
& $\mathrm{~N}$ & 15 & \\
\hline \multicolumn{2}{l}{ Correlation is significant at the 0.01 level (2-tailed) }
\end{tabular}

The non-standardized coefficients from column B are used to formulate the regression equation while the Beta coefficients are employed in the comparison of the contributions of all the dependent variables. One of the aims of this paper is to compare the contributions of dependent variables, i.e. the impact of GDP per capita as well as the shares of industry and of service in GDP on transport emissions; thus special attention is paid to the analysis of the Beta coefficients.

Table 5 The impact of GDP per capita, the shares of industry and of service in transport GHG emissions in cluster 1

\begin{tabular}{clccc}
\hline Model & R & R Square & Adjusted R Square & Std. Error of the Estimate \\
\hline 1 & $0.952^{\mathrm{a}}$ & 0.906 & 0.881 & 1.22370 \\
2 & $0.947^{\mathrm{b}}$ & 0.897 & 0.880 & 1.22801 \\
\hline \multicolumn{5}{c}{ a. Predictors: (Constant), service, GDP per capita, industry } \\
& b. Predictors: (Constant), service, GDP per capita \\
& c. Dependent Variable: transport GHG emissions
\end{tabular}

Based on the results of the regression analysis given in Table 5 (prepared by the authors - SPSS Statistics 19.0) it can be seen that the coefficient of determination is 0.906 if we consider the impact of GDP per capita as well as the shares of industry and of service in GDP on transport GHG emissions; but if we consider only the impact of GDP per capita and share of service in GDP on transport GHG emission the coefficient of determination is 0.897 . When expressed as a percentage, we can conclude that the combined impact of all the independent variables on transport GHG emissions is $90.6 \%$ or $89.7 \%$ if we consider only the impact of GDP per capita and the share of service in GDP. It is necessary to point out that the value of Sig. is less than $0.05(0.001)$, and then the contribution observed is statistically significant.

To avoid multicollinearity between the independent variables applied within the regression analysis is the method backward. The results of the analysis of the impact of the observed variables for cluster 1 are given in Table 6 (prepared by the authors - SPSS Statistics 19.0). The results of the regression analysis indicate that GDP per capita and the share of service in GDP have a statistically significant impact on transport GHG emissions. 
Table 6 The value of regression coefficients - influence of GDP per capita, the shares of industry and of service in GDP on transport GHG emissions

\begin{tabular}{|c|c|c|c|c|c|}
\hline & \multirow[t]{2}{*}{ Model } & \multicolumn{2}{|c|}{$\begin{array}{l}\text { Unstandardized } \\
\text { Coefficients }\end{array}$} & \multirow{2}{*}{$\begin{array}{c}\begin{array}{c}\text { Standardized } \\
\text { Coefficients }\end{array} \\
\text { Beta }\end{array}$} & \multirow[t]{2}{*}{ Sig. } \\
\hline & & B & Std. Error & & \\
\hline \multirow{4}{*}{1} & (Constant) & 197.219 & 64.936 & & 0.011 \\
\hline & GDP per capita & 0.000 & 0.000 & 0.727 & 0.000 \\
\hline & Industry & -0.716 & 0.687 & -0.755 & 0.320 \\
\hline & Service & -1.858 & 0.665 & -2.047 & 0.017 \\
\hline \multirow{3}{*}{2} & (Constant) & 130.001 & 7.165 & & 0.000 \\
\hline & GDP per capita & 0.0004 & 0.000 & 0.724 & 0.000 \\
\hline & Service & -1.176 & 0.117 & -1.296 & 0.000 \\
\hline
\end{tabular}

Based on the results of the regression analysis for cluster 2 given in Table 7 (prepared by the authors - SPSS Statistics 19.0) it can be seen that the coefficient of determination is 0.915 if we consider the impact of GDP per capita, the shares of industry and of service in GDP on transport GHG emissions. However, if we consider the impact of the shares of industry and of service in GDP on transport GHG emissions then the coefficient of determination is 0.914 ; but if we consider only the impact of the share of service in GDP on transport GHG emission the coefficient of determination is 0.895 . When expressed as a percentage, we can conclude that the combined impact of all the independent variables on transport GHG emissions is $91.5 \%$ or $91.4 \%$ if we consider the impact of the share of industry and of service in GDP or $89.5 \%$ if we consider only the impact of the share of industry. It is necessary to point out that the value of Sig. is less than $0.05(0.001)$, and then the contribution observed is statistically significant.

Table 7 The impact of GDP per capita, of the shares of industry and of service on transport GHG emissions in cluster 2

\begin{tabular}{ccccc}
\hline Model & R & R Square & Adjusted R Square & Std. Error of the Estimate \\
\hline 1 & $0.956^{\mathrm{a}}$ & 0.915 & 0.892 & 0.45234 \\
2 & $0.956^{\mathrm{b}}$ & 0.914 & 0.900 & 0.43458 \\
3 & $0.946^{\mathrm{c}}$ & 0.895 & 0.887 & 0.46237 \\
\hline \multicolumn{5}{c}{ a. Predictors: (Constant), service, GDP per capita, industry } \\
& b. Predictors: (Constant), service, industry & \\
& c. Predictors: (Constant), industry & \\
& d. Dependent Variable: transport GHG
\end{tabular}

The results of the analysis of the impact of the observed variables for cluster 2 are given in Table 8 (prepared by the authors - SPSS Statistics 19.0). The results of regression analysis indicate that the share of industry in GDP has a statistically significant impact on transport GHG emissions. 
Table 8 The value of regression coefficients - influence of GDP per capita, the shares of industry and of service in GDP on transport GHG emissions in cluster 2

\begin{tabular}{llrcc}
\hline \multirow{2}{*}{ Model } & \multicolumn{2}{c}{$\begin{array}{c}\text { Unstandardized } \\
\text { Coefficients }\end{array}$} & $\begin{array}{c}\text { Standardized } \\
\text { Coefficients }\end{array}$ & Sig. \\
\cline { 2 - 5 } & \multicolumn{1}{c}{ B } & Std. Error & Beta & \\
\hline (Constant) & -87.660 & 85.547 & & 0.328 \\
1 GDP per capita & $-7.645 \mathrm{E}-6$ & 0.000 & -0.063 & 0.788 \\
industry & 1.865 & 0.878 & 2.653 & 0.057 \\
service & 1.125 & 0.881 & 1.767 & 0.228 \\
(Constant) & -70.982 & 58.116 & & 0.245 \\
2 industry & 1.705 & 0.634 & 2.426 & 0.020 \\
service & 0.946 & 0.574 & 1.487 & 0.125 \\
(Constant) & 24.748 & 1.757 & & 0.000 \\
industry & 0.665 & 0.063 & 0.946 & 0.000 \\
\hline
\end{tabular}

The coefficient of determination shows how much of the variance of the dependent variable was explained by the model. The coefficient of determination is 0.976 (Table 9) (prepared by the authors - SPSS Statistics 19.0). When expressed as a percentage, it can be concluded that the joint impact of the GDP per capita and of the shares of industry and of service in GDP on transport GHG emissions is $97.6 \%$ in cluster 3. It is necessary to point out that the value of Sig. is less than 0.05 (0.001), and then the contribution observed is statistically significant.

Table 9 The impact of the GDP per capita, the shares of industry and of service on the transport GHG emissions in cluster 3

\begin{tabular}{ccccc}
\hline Model & R & R Square & Adjusted R Square & Std. Error of the Estimate \\
\hline 1 & $0.988^{\text {a }}$ & 0.976 & 0.970 & 0.24140 \\
\hline \multicolumn{5}{c}{ a. Predictors: (Constant), service, industry, GDP per capita } \\
b. Dependent Variable: transport GHG emissions
\end{tabular}

Table 10 The value of regression coefficients - influence of GDP per capita, the shares of industry and of service in GDP on transport GHG emissions in cluster 3

\begin{tabular}{|c|c|c|c|c|c|}
\hline & \multirow[t]{2}{*}{ Model } & \multicolumn{2}{|c|}{$\begin{array}{l}\text { Unstandardized } \\
\text { Coefficients }\end{array}$} & \multirow{2}{*}{$\begin{array}{c}\begin{array}{c}\text { Standardized } \\
\text { Coefficients }\end{array} \\
\text { Beta }\end{array}$} & \multirow[b]{2}{*}{ Sig. } \\
\hline & & B & Std. Error & & \\
\hline \multirow{4}{*}{1} & (Constant) & -92.016 & 18.680 & & 0.000 \\
\hline & GDP per capita & 0.0001 & 0.000 & 0.377 & 0.013 \\
\hline & industry & 1.247 & 0.229 & 0.522 & 0.000 \\
\hline & Service & 0.967 & 0.196 & 0.771 & 0.000 \\
\hline
\end{tabular}

a. Dependent Variable: transport GHG emissions

The results of the analysis of the impact of the observed variables for cluster 3 are given in Table 10 (prepared by the authors - SPSS Statistics 19.0). The results of the regression analysis indicate that the GDP per capita as well as the shares of industry in GDP and of service in GDP have a statistically significant impact on transport GHG emissions. 
The results of the regression analysis indicate that changes in the economic structure, i.e. changes in the industrial participation in GDP, as well as changes in the service sector participation in GDP, exert a significant influence on transport GHG emissions. The above research results confirm hypothesis $\mathrm{H}_{2}$.

\section{CONCLUDING REMARKS}

The results of the cluster and correlation analysis have shown that the inverted-Ushaped relationship exists between GDP per capita and transport GHG emissions in the highly developed countries as well as transition in the EU. While the highly developed countries record a decrease in transport GHG emissions with an increase in GDP per capita, the transition countries record an increase in transport GHG emissions with an increase in GDP per capita.

The results of the regression analysis indicate the following:

1) An increase in the service sector participation in GDP leads to a decrease in transport GHG emissions in the countries belonging to cluster 1;

2) An increase in the industrial participation in GDP leads to an increase in transport GHG emissions in the highly developed countries, i.e. the countries belonging to cluster 2 ;

3) An increase in the industrial participation in GDP, as well as an increase in the service sector participation in GDP, contributes to an increase in transport GHG emissions in transition countries, i.e. the countries belonging to cluster 3 .

The results show that an increase in the industrial participation in GDP in the highly developed countries, but also in the transition countries, leads to an increase in transport GHG emissions, while an increase in the service sector participation in GDP in the countries belonging to cluster 1 , i.e. the countries with a recorded higher level of GDP per capita in comparison with the transition countries, contributes to a decrease in transport GHG emissions. However, an increase in the service sector participation in GDP in the transition countries leads to an increase in transport GHG emissions.

\section{REFERENCES}

1. Krstić, B., Petrović, J., Stanišić, T., 2015, Influence of education system quality on the use of ICT in transition countries in the age of information society, Teme, 3, pp. 747-763.

2. Pamučar, D., Ćirović, G., 2018, Vehicle route selection with an adaptive neuro fuzzy inference system in uncertainty conditions, Decision Making: Applications in Management and Engineering, 1(1), pp. 13-37.

3. UN (United Nations), 2016, Urbanization and development: Emerging Futures, World Cities Report 2016, United Nations Human Settlements Programme, from: http://wcr.unhabitat.org, (Accessed on 5 Dec. 2016).

4. Yihui, T., Qinghua, Z., Kee-Hung, L., , Venus, Y.H.L., 2014, Analysis of greenhouse gas emissions of freight transport sector in China, Journal of Transport Geography, 40, pp. 43-52.

5. IEA (International Energy Agency), 2012, $\mathrm{CO}_{2}$ Emissions from Fuel Combustion, IEA Publications, France.

6. Burak, S.A., 2017, Testing the environmental Kuznets curve hypothesis across the U.S.: Evidence from panel mean group estimators, Renewable and Sustainable Energy Reviews, 77, pp. 731-747.

7. Ajanovic, A., Dahl, C., Schipper, L., 2012, Modelling transport (energy) demand and policies - an introduction, Energy Policy, 41, pp. iii-xiv.

8. Grossman, G.M., Alan, B.K., 1991, Environmental Impact of a North American Free Trade Agreement, Working Paper 3914, National Bureau of Economic Research, Cambridge, MA.

9. Munasinghe, M., 1999, Is Environmental Degradation an Inevitable Consequence of Economic Growth: Tunneling Through the Environmental Kuznets Curve, Ecological Economics, 29(1), pp. 89-109. 
10. Muhammad, A., Abdul, Q.K., 2016, Testing the Environmental Kuznets Curve hypothesis: A comparative empirical study for low, lower middle, upper middle and high income countries, Renewable and Sustainable Energy Reviews, 63, pp. 556-567.

11. Nilsson, L.J., 1993, Energy intensity trends in 31 industrial and developing countries: 1950-1988, Energy, 18(4), pp. 309-322.

12. Vukina, T., Beghin, J.C., Solakoglu, E.G., 1999, Transition to markets and the environment: effects of the change in the composition of manufacturing output, Environment and Development Economics, 4(4), pp. 582-598.

13. Krstić, B., Petrović, J., 2017, Interdependence of competitiveness and productivity of national economies - The case of EU member countries, Enhancing micro and macro competitiveness - possibilities and limitations, University of Niš, Faculty of Economics, Niš, pp. 1-21.

14. Anjum, Z., Burke, P.J., Gerlagh, R., Stern, D.I., 2014, Modeling the emissions-income relationship using longrun growth rates, CCEP Working Papers 1403, Centre for Climate Economics \& Policy, Crawford School of Public Policy, The Australian National University.

15. Blanco, G., Gerlagh, R., Suh, S., Barrett, J., de Coninck, H., Morejon, C.F. Diaz, Mathur, R., Nakicenovic, N., Ahenkorah, A.O., Pan, J., Pathak, H., Rice, J., Richels, R., Smith, Steven J., Stern, David I., Toth, F.L., Zhou, P., 2014, Drivers, trends and mitigation. In: Edenhofer, O., et al. (Eds.), Contribution of Working Group III to the Fifth Assessment Report of the Intergovernmental Panel on Climate Change Climate Change 2014: Mitigation of Climate Change. Cambridge University Press, Cambridge, UK and New York, NY, USA.

16. Ehrlich, P.R. and Holdren, J.P., 1971, Impact of population growth, Science, 171(3977), pp.1212-1217.

17. Sanchez, L., Stern, D., 2016, Drivers of industrial and non-industrial greenhouse gas emissions, Ecological Economics, 124, pp. 17-24

18. Kuznets, S., 1955, Economic Growth and Income Inequality, American Economic Review, 45(1), pp. 1-28.

19. Alshehrya, A. S., Belloumia, M., 2017, Study of the environmental Kuznets curve for transport carbon dioxide emissions in Saudi Arabia, Renewable and Sustainable Energy Reviews, 75, pp. 1339-1347.

20. Grossman, G.M., Krueger, A.B., 1991, Environmental impacts of the North American Free Trade Agreement, NBER Working paper, 3914.

21. Shafik, N., 1994, Economic development and environmental quality: an econometric analysis, Oxford Economic Papers, 46, pp. 757-773.

22. Panayotou, T., 1993, Empirical tests and policy analysis of environmental degradation at different stages of economic development, ILO, Technology and Employment Programme, Geneva.

23. Dijkgraaf, E., Vollebergh, HRJ., 1998, Growth and/or environment: is there a kuznets curve for carbon emissions?, Proc. Second biennial meeting of the european society for ecological economics, Geneva.

24. Dinda, S., 2009, Climate change and human insecurity, International Journal of Global Environmental, 9(1/2), pp. 103-109.

25. Han, X.M., Zhang, M.L., Liu, S., 2011, Research on the relationship of economic growth and environmental pollution in Shandong province based on environmental Kuznets curve, Energy Procedia, 5, pp. 508-12

26. Jalil, A., Mahmud, S.F., 2009, Environmental Kuznets curve for $\mathrm{CO}_{2}$ emission: a cointegration analysis for China, Energy Policy, 37, pp. 5167-5172.

27. Kristrom, B., Lundgren, T., 2003, Swedish $\mathrm{CO}_{2}$ emissions 1900-2010: An exploratory note, Energy Policy, 33 , pp. 1223-1230.

28. Lamla, M.J., 2009, Long-run determinants of pollution: a robustness analysis, Ecological Economics, 69(1), pp. 135-144.

29. Pao, H.T, Tsai, C.M., 2011, Modeling and forecasting the $\mathrm{CO}_{2}$ emissions, energy consumption, and economic growth in Brazil, Energy, 36, pp. 2450-2458.

30. Schmalensee, R., Stoker, T.M., Judson, R.A., 1998, World carbon dioxide emissions: 1950-2050, Review of Economics and Statistics, 80(1), pp. 15-27.

31. Stern, D.I., Common, M.S., Barbier, E.B., 1996, Economic growth and environmental degradation: the environmental Kuznets curve and sustainable development, World Development, 24(7), pp. 1151-1160.

32. European Commission, 2016, Statistical pocketbook: EU transport in figures, Bietlot, Belgium.

33. The World Bank, World Development Indicators, http://databank.worldbank.org/data/databases.aspx, (last access: 1st July 2017) 